\title{
Tyrosinase Inhibitory Activity of Garcinia latissima Miq. Extracts
}

\author{
Neneng Siti Silfi Ambarwati ${ }^{1 *}$, Berna Elya ${ }^{2}$, Yesi Desmiaty ${ }^{3}$, Ayun Erwina Arifianti ${ }^{4}$, Islamudin Ahmad ${ }^{5}$
}

Neneng Siti Silfi Ambarwati ${ }^{1, *}$, Berna Elya², Yesi Desmiaty ${ }^{3}$, Ayun Erwina Arifianti ${ }^{4}$, Islamudin Ahmad $^{5}$

'Cosmetology Department, Faculty of Engineering, Universitas Negeri Jakarta, J. Rawamangun Muka, East Jakarta, Jakarta 13220, INDONESIA

${ }^{2}$ Laboratory of Pharmacognosy and Phytochemistry, Faculty of Pharmacy, Universitas Indonesia, Depok, West Java 16424, INDONESIA.

${ }^{3}$ Laboratory of Pharmacognosy, Faculty of Pharmacy, Universitas Pancasila, Jl.

Srengseng Sawah, Jagakarsa, South Jakarta Jakarta 12640, INDONESIA.

${ }^{4}$ Laboratory of Pharmaceutics and

Pharmaceutical Technology, Faculty of

Pharmacy, Universitas Indonesia, Depok, West Java 16424, INDONESIA.

${ }^{5}$ Department of Pharmaceutical Sciences,

Faculty of Pharmacy, Universitas

Mulawarman, Samarinda, East Kalimantan,

INDONESIA.

\section{Correspondence}

\section{Neneng Siti Silfi Ambarwati}

Cosmetology Department, Faculty of

Engineering, Universitas Negeri Jakarta, JI.

Rawamangun Muka, East Jakarta, Jakarta

13220, INDONESIA.

Phone no: +6281399439923

E-mail: neneng_ambarwati@yahoo.co.id

History

- Submission Date: 13-09-2021;

- Review completed: 02-10-2021;

- Accepted Date: 11-10-2021.

DOI : 10.5530/pj.2021.13.215

Article Available online

http://www.phcogj.com/v13/i6

Copyright

(C) 2021 Phcogj.Com. This is an openaccess article distributed under the terms of the Creative Commons Attribution 4.0 International license.

\begin{abstract}
Background: Tyrosinase is an enzyme that plays an essential part in the process of melanin synthesis High exposure to ultraviolet (UV) radiation or high stimulation of melanocytes could cause excessive melanin pigments to lead to hyperpigmentation. Objective: This study aimed to find potential natural skin lightening ingredients from Garcinia latissima Miq. Methods: Stem bark, fruits, and leaves of Garcinia latissima Miq. were extracted with successive maceration. The tyrosinase inhibitory activity test was measured spectrophotometrically at $490 \mathrm{~nm}$ using 3,4-dihydroxy-L-phenylalanine (L-DOPA) as substrate and kojic acid as a positive control. Results: The tyrosinase inhibitory activity test at a concentration of 100 ppm showed that the bark ethyl acetate extract $15.94 \% \pm 7.70$, bark methanol extract of $28.94 \% \pm 5.73$, fruit $n$-hexane extract $25.16 \% \pm 10.22$, fruit methanol extract $23.26 \% \pm 9.10$; and leaf methanol extract $30.59 \% \pm 0.63$ with kojic acid inhibition $65.07 \%$. Conclusion: Methanol extract of leaf from Garcinia latissima Miq was the most active extract as a tyrosinase inhibitor.
\end{abstract}

Key words: Succesive maceration, Extract, Tyrosinase, Garcinia latissima Miq

\section{INTRODUCTION}

The plant of Garcinia family hasn't been much tested for its tyrosinase. There are some plants from Garcinia family that have been tested for their tyrosinase. They are : G. daedalanthera Pierre, G. atroviridis Griff., G. xanthochymus, G. livingstonei, and G. kola ${ }^{1-4}$.

Tyrosinase is enzyme that has a role to develop skin pigmen. The inhibition of this enzyme can help to lighten the skin ${ }^{5}$. The inhibition of the tyrosinase enzyme can be tested in vitro by using spectrophotometric ${ }^{6}$. Tyrosinase test of this plant has not been published yet.

Tyrosinase is an enzyme that catalyzes the hydroxylation of tyrosine into 3,4-dihydroxyL-phenylalanine (L-DOPA), oxidized L-DOPA into hydroxy indole, oxidized into dopaquinone and after several transformations in melanin biosynthesis ${ }^{7}$. Melanin has a significant role in skin protection from ultraviolet (UV), but excessive melanin synthesis can cause hyperpigmentation ${ }^{8}$. Tyrosinase inhibition is the most used way in the skin depigmentation process ${ }^{5}$.

Garcinia latissima Miq. as an indigenous plant from Seram Island, Maluku, and Papua, is known as Dolo magota, but already cultivated in Bogor Botanical Garden, Jawa Barat ${ }^{9}$. It had been proven qualitatively in the previous research that ethyl acetate extract of bark, methanol extract of bark, ethyl acetate extract of the fruit, and methanol extract of fruit from Garcinia latissima Miq. contained flavonoid ${ }^{10,11}$. Anti-oxidant test and anti-elastase test of this G. latissima Miq. have been conducted ${ }^{12-14}$. By conducting anti-tyrosinase test of $G$. latissima Miq., it can be utilized for cosmetics substance.

Flavonoid containing natural resources can inhibit tyrosinase activity directly in melanogenesis.
Flavonoid is a secondary metabolite that has a polyphenol structure and important component in drugs and cosmetics. Flavonoid is also known as a strong inhibitor for several enzymes ${ }^{15}$. Flavonoid has an important role in inhibiting tyrosinase in melanogenesis. Therefore, able to be a depigmentation agent through bonding with copper and antioxidant mechanism ${ }^{16}$. This research aimed to examine and prove the tyrosinase inhibitor scientifically from Garcinia latissima Miq. extracts.

\section{MATERIALS AND METHODS}

\section{Materials and Equipment}

Garcinia latissima Miq. was cultivated from Bogor Botanical Garden, and part of bark, leaves, and fruit was used. The solvent used for extraction was n-hexane, ethyl acetate, and methanol (Duta Pratama Chemica, Bogor, Indonesia), lyophilized mushroom tyrosinase $\geq 1000 \mathrm{unit} / \mathrm{mg}$ (Sigma Aldrich, Singapore), 3,4-dihydroxyphenylalanine (Sigma Aldrich, Singapore), and kojic acid (Thornhill, Kanada). Rotary evaporator (Buchi R-205, Germany), ELISA Microplate Reader (VersaMaxTM, USA) in Phytochemistry Labotarory in Faculty of Pharmacy, Universitas Indonesia.

\section{Extraction Process}

Extraction process was conducted by multiple maceration method using three different solvents with a different polarity such as n-hexane, ethyl acetate, and methanol. Each of the materials including fruit, leaf and bark was dried, powdered, and soaked by using solvent for 24 hours. After that each of the extract was dried and tested.

\section{Tyrosinase Inhibitory Activity Assay}

The tyrosinase inhibitory activity assay was using mushroom tyrosinase lyophilized powder, 3,4-dihydroxylphenylalanine (L-DOPA) as substrate, 
Table 1: Result of tyrosinase inhibitory activity test at sample concentration $100 \mathrm{ppm}$.

\begin{tabular}{|c|c|c|c|c|c|}
\hline No. & Sample of G. latissima & Absorbance 1 & Absorbance 2 & Absorbance 3 & $\begin{array}{c}\text { Tyrosinase inhibitory } \\
\text { activity }(\%)^{*}\end{array}$ \\
\hline 1. & ethyl acetate extract of bark & 0.64 & 0.73 & 0.69 & $15.61 \pm 5.48$ \\
\hline 2. & methanol extract of bark & 0.63 & 0.56 & 0.54 & $28.94 \pm 5.73$ \\
\hline 3. & n-hexane extract of fruit & 0.62 & 0.52 & 0.68 & $25.16 \pm 10.22$ \\
\hline 4. & methanol extract of fruit & 0.64 & 0.69 & 0.54 & $23.26 \pm 9.10$ \\
\hline 5. & methanol extract of leaf & 0.56 & 0.57 & 0.56 & $30.59 \pm 0.63$ \\
\hline 6. & Kojic acid & 0.29 & 0.28 & 0.28 & $65.07 \pm 0.86$ \\
\hline
\end{tabular}

${ }^{*}$ Result in triplicate

and kojic acid as the standard ${ }^{1718}$. Phosphate buffer $(120 \mu \mathrm{L}, 0.1 \mathrm{M}, \mathrm{pH}$ 6.8), L-DOPA solution (18.488 $\mathrm{mM})$, sample solution (100 ppm), and tyrosinase $(250 \mathrm{U} / \mathrm{mL})$ was added in 96-well-plate based on method optimation ${ }^{19}$. Each sample was used a control without tyrosinase ${ }^{20}$. Blank was using DMSO and blank control without enzyme ${ }^{21}$. After $10 \mathrm{~min}$ incubation at $37^{\circ} \mathrm{C}$, then absorbance was measured using a microplate reader at $490 \mathrm{~nm}$, triplicate ${ }^{22}$.

Inhibition percentage was calculated using formula below ${ }^{23}$ :

$\%$ inhibition $=\frac{(\text { A_B })-(C-D)}{(A-B)} \times 100$

where A is blank absorption, B is control blank, C is sample, and D sample control.

\section{RESULTS}

Results of the tyrosinase inhibitory activity test can be seen in Table 1 .

\section{DISCUSSION AND CONCLUSION}

The result showed Garcinia latissima Miq. extract either from leaves, bark, and fruit had an inhibitory activity but lowered from kojic acid. Kojic acid is a synthetic tyrosinase inhibitor that has been reported and used as a skin-lightening agent in cosmetics ${ }^{24}$. Unfortunately, there are several side effects while using kojic acid, such as erythema and contact dermatitis; therefore, natural products are needed to replace this ${ }^{24}$.

In this research, the tyrosinase enzyme was isolated and purified from Agaricus biosporus mushroom. It is the primary source of tyrosinase enzyme, affordable, and posses high similarity and homology with human tyrosinase, dan found by Bourquelot and Bertrand since 1895 Mushroom tyrosinase has two copper, interacts with oxygen in the active site, and is bonded with six histidines ${ }^{25}$.

The substrate used in this research was L-DOPA that is o-diphenol and can be oxidized by tyrosinase into o-quinone (dopaquinone); in contrast, the tyrosinase itself becomes deoxy-tyrosinase ${ }^{25}$. The two molecules of dopaquinone will change into dopachrome that can be measured with UV-spectrophotometry at $490 \mathrm{~nm}^{26}$.

The highest tyrosinase inhibitory in Garcinia latissima Miq. was leaf methanol extract $(30.59 \pm 0.63 \%)$, but still lower than kojic acid $(65,07$ $\%)$. Further research was needed to isolate the bioactive compound from the leaf methanol extract in Garcinia latissima Miq. Another research from the similar genus Garcinia subelliptica was reported to find an isolate of dimer flavon-flavon as a tyrosinase inhibitor and higher than kojic acid ${ }^{27}$. The activity of methanol extract G. subelliptica in $500 \mathrm{ppm}$ as a tyrosinase inhibitor was reported $57.2 \pm 2.2 \%$ showed a strong tyrosinase inhibitory ${ }^{28}$.

Natural ingredients, especially plants and plant extracts, which have activity as an inhibitor of the activity of the tyrosinase enzyme and inhibit melanin production can be used as an ingredient to maintain skin brightness or a whitening agent, which is usually found in cosmetic preparations ${ }^{29}$. The antioxidant activity of skin lightening is also related to the inactivation of the melanogenesis process. UV radiation produces reactive oxygen species (ROS) which can activate the tyrosinase enzyme in the skin and cause melanogenesis because the enzymes prefer superoxide anion radicals ${ }^{29}$. The leaf methanol extract G. latissima Miq. is most active and most potential as tyrosinase inhibitory activity, so it can be further investigated by fractionating or isolating the extract.

Biflavonoid compound of Garcinia has been reported to have a competitive mechanism naturally and unique to tyrosinase based on an in-vitro test ${ }^{30}$. Based on molecular docking, the mechanism of the biflavonoid compound is ligand interaction with copper in the active site ${ }^{30}$. This research showed hydrogen bond interaction between Glu322, His85, and His263 residue with a hydroxyl group in monoflavonoid subunit and formed a complex of stable biflavonoid-tyrosinase. Biflavonoid compound is a promising agent for dermatological disturbance related to hyperpigmentation ${ }^{30}$.

The conclusion of the research is the leaf methanol extract of Garcinia latissima Miq. showed a strong tyrosinase inhibitory, probably due to biflavonoid compound.

\section{ACKNOWLEDGMENTS}

This research was supported and funded by HIBAH PENELITIAN KOLABORATIF NASIONAL 2021 UNIVERSITAS NEGERI JAKARTA with contract number of 3/PKM/LPPM/IV/2021.

\section{CONFLICTS OF INTEREST}

The authors declared no conflicts of interest.

\section{REFERENCES}

1. Ambarwati NSS, Elya B, Desmiaty Y, Ahmad I. Tyrosinase inhibitory activity of Garcinia daedalanthera Pierre. J Phys Conf Ser. 2021;1869(1). doi:10.1088/1742-6596/1869/1/012019

2. Chatatikun $M$, Supjaroen $P$, Promlat $P$, et al. Antioxidant and tyrosinase inhibitory properties of an aqueous extract of Garcinia atroviridis Griff. ex. T. Anderson fruit pericarps. Pharmacogn J. 2020;12(1):71-78. doi:10.5530/pj.2020.12.12

3. Ambarwati NSS, Elya B, Desmiaty Y, Atmanto D, Ahmad I. Tyrosinase inhibitory activity of Garcinia xanthochymus fruit pericarp extract. AIP Conf Proc. 2021;2331(April):10-14. doi:10.1063/5.0041813

4. Opperman L, De Kock M, Klaasen J, Rahiman F. Tyrosinase and melanogenesis inhibition by indigenous African plants: A review. Cosmetics. 2020;7(3):1-14. doi:10.3390/COSMETICS7030060

5. Pillaiyar T, Manickam M, Namasivayam V. Skin whitening agents: Medicinal chemistry perspective of tyrosinase inhibitors. J Enzyme Inhib Med Chem. 2017;32(1):403-425. doi:10.1080/14756366.2016 .1256882

6. Zolghadri S, Bahrami A, Hassan Khan MT, et al. A comprehensive review on tyrosinase inhibitors. J Enzyme Inhib Med Chem. 2019;34(1):279-309. doi:10.1080/14756366.2018.1545767 
7. Charissa M, Djajadisastra J, Elya B. Uji Aktivitas Antioksidan dan Penghambatan Tirosinase serta Uji Manfaat Gel Ekstrak Kulit Batang Taya (Nauclea subdita) terhadap Kulit. J Kefarmasian Indones. 2017;6(2):98-107. doi:10.22435/jki.v6i2.6224.98-107

8. Brenner M, Hearing VJ. The Protective Role of Melanin Against UV Damage in Human Skin. Photochem Photobiol. 2014;23(1):1-7. doi:10.1111/j.1751-1097.2007.00226.x.The

9. Ambarwati NSS, Elya B, Malik A, Hanafi M. Evaluation of antimicrobial activities of Garcinia Latissima Miq. Stem bark extract. J Young Pharm. 2017;9(1):S56-S59. doi:10.5530/jyp.2017.1s.15

10. Ambarwati NSS, Ahmad I, Elya B, Malik A, Hanafi M. Pharmacognostic and Antimicrobial Studies of $<i>$ Garcinia latissima $<i>$ Miq. Leaves (Clusiaceae). Pharmacogn J. 2017;9(4):493-498. doi:10.5530/ pj.2017.4.80

11. Ambarwati NSS, Elya B, Malik A, Hanafi M. Phytochemical and antimicrobial studies on Garcinia lattissima Miq. Fruit extract. Asian J Pharm Clin Res. 2017;10(7):230-232. doi:10.22159/ajpcr.2017. v10i7.18528

12. Ambarwati NSS, Elya B, Desmiaty $Y$. Anti-elastase activity of methanolic and ethyl acetate extract from Garcinia latissima Miq. J Phys Conf Ser. 2019;1402(5). doi:10.1088/1742-6596/1402/5/055079

13. Ambarwati NSS, Elya B, Malik A, et al. Antibacterial and Antioxidant Activities of Fractions from Garcinia latissima Miq. Stem Bark Methanol Extract. Int J Pharm Clin Res. 2019;11(2):63-67.

14. Ambarwati NSS, Elya B, Nur A, Puspitasari N, Malik A, Hanafi M. Activity of Fractions from Garcinia latissima Miq. Leaves Ethyl Acetate Extract as Antibacterial Against Bacillus subtilis and Antioxidant. Adv Sci Lett. 2018;24(9):6366-6370. doi:10.1166/asl.2018.12717

15. Panche AN, Diwan AD, Chandra SR. Flavonoids: An overview. J Nutr Sci. 2016;5. doi:10.1017/jns.2016.41

16. Dolorosa MT, Nurjanah, Purwaningsih S, Anwar E, Hidayat T. Tyrosinase inhibitory activity of Sargassum plagyophyllum and Eucheuma cottonii methanol extracts. IOP Conf Ser Earth Environ Sci. 2019;278(1). doi:10.1088/1755-1315/278/1/012020

17. Bang EJ, Noh SG, Ha S, et al. Evaluation of the novel synthetic tyrosinase inhibitor (z)-3-(3-bromo-4-hydroxybenzylidene) thiochroman-4-one (MHY1498) In vitro and in silico. Molecules. 2018;23(12):1-11. doi:10.3390/molecules23123307

18. Pintus F, Spanò D, Corona A, Medda R. Antityrosinase activity of Euphorbia characias extracts. PeerJ. 2015;2015(10). doi:10.7717/ peerj.1305
19. Yoon KN, Atom N, Lee JS, Lee KR, Lee TS. Detection of phenolic compounds concentration and evaluation of antioxidant and antityrosinase activities of various extracts from the fruiting bodies of lentinus edodes. World Appl Sci J. 2011;12(10):1851-1859.

20. Promden W, Viriyabancha W, Monthakantirat O, Umehara K, Noguchi H, De-Eknamkul W. Correlation between the potency of flavonoids on mushroom tyrosinase inhibitory activity and melanin synthesis in melanocytes. Molecules. 2018;23(6):1-11. doi:10.3390/ molecules23061403

21. Etsassala NGER, Waryo T, Popoola OK, Adeloye AO, Iwuoha El, Hussein AA. Electrochemical screening and evaluation of lamiaceae plant species from South Africa with potential tyrosinase activity. Sensors (Switzerland). 2019;19(5). doi:10.3390/s19051035

22. Kim JH, Baek SH, Kim DH, et al. Downregulation of melanin synthesis by haginin $A$ and its application to in vivo lightening model. J Invest Dermatol. 2008;128(5):1227-1235. doi:10.1038/sj.jid.5701177

23. Chintong S, Phatvej W, Rerk-Am U, Waiprib Y, Klaypradit W. In vitro antioxidant, antityrosinase, and cytotoxic activities of astaxanthin from shrimpwaste. Antioxidants. 2019;8(5):1-11. doi:10.3390/ antiox8050128

24. Cui H, Duan F, Jia S, Cheng F, Yuan K. Antioxidant and Tyrosinase Inhibitory Activities of Seed Oils from Torreya grandis Fort . ex Lindl . Hindawi BioMed Res Int. 2018;2018:1-10. doi:10.1155/2018/5314320

25. Zolghadri S, Bahrami A, Tareq M, et al. A Comprehensive Review on Tyrosinase Inhibitors. J Enzyme Inhib Med Chem. 2019;34(1):279309. doi:10.1080/14756366.2018.1545767

26. Juwita NK, Djajadisastra J. UJI PENGHAMBATAN TIROSINASE DAN YANG MENGANDUNGEKSTRAK KULIT BATANG NANGKA ( Artocarpus heterophyllus ). Maj Ilmu Farm. 2013;8(3):127-140.

27. Mukherjee PK, Biswas R, Sharma A, Banerjee S, Biswas S, Katiyar CK. Validation of medicinal herbs for anti-tyrosinase potential. J Herb Med. 2018;14(September):1-16. doi:10.1016/j.hermed.2018.09.002

28. Masuda $T$, Yamashita D, Takeda $Y$, Yonemori S. Screening for tyrosinase inhibitors among extracts of seashore plants and identification of potent inhibitors from Garcinia subelliptica. Biosci Biotechnol Biochem. 2005;69(1):197-201. doi:10.1271/bbb.69.197

29. Muddathir AM, Yamauchi K, Batubara I, Mohieldin EAM, Mitsunaga T. Anti-tyrosinase, total phenolic content and antioxidant activity of selected Sudanese medicinal plants. South African J Bot. 2017:109:915. doi:10.1016/j.sajb.2016.12.013

30. Happy OT. Ab Initio Modeling and Garcinia Biflavonoids-Binding Study of Tyrosinase: The Signature Enzyme of Melanogenesis. J Appl Bioinforma Comput Biol. 2018;07(02). doi:10.4172/23299533.1000149 


\section{GRAPHICAL ABSTRACT}

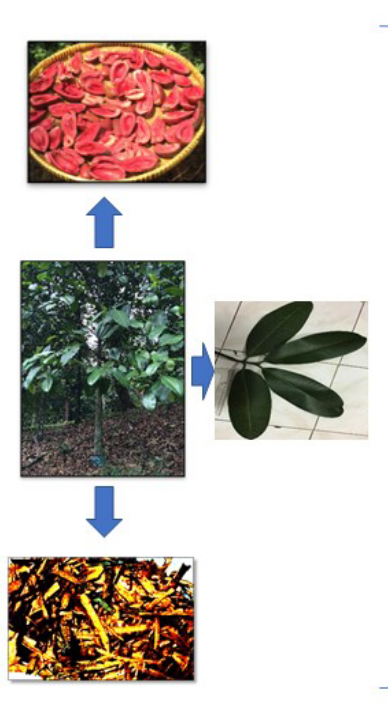

Garcinia latissima Miq.

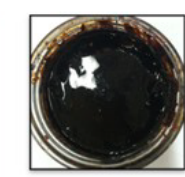

the bark ethyl acetate extract

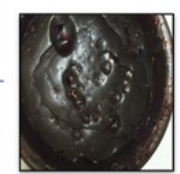

bark methanol extract

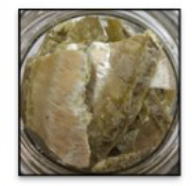

fruit $\mathrm{n}$-hexane extract

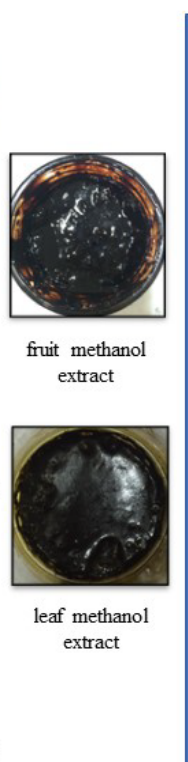

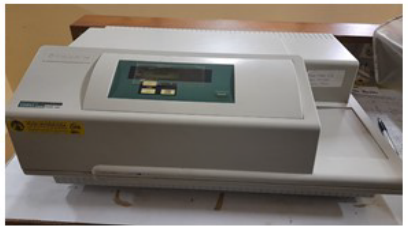

The tyrosinase inhibitory activity test by microplate reader

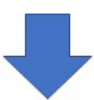

\begin{tabular}{|c|c|c|c|c|c|}
\hline No. & $\begin{array}{l}\text { Sample of G. } \\
\text { latissima }\end{array}$ & $\begin{array}{c}\text { Absorbance } \\
1\end{array}$ & $\begin{array}{c}\text { Absorbance } \\
2\end{array}$ & $\begin{array}{c}\text { Absorbance } \\
3\end{array}$ & $\begin{array}{c}\text { Tyrosinase } \\
\text { inhibitory activity } \\
(\%)^{*}\end{array}$ \\
\hline 1. & $\begin{array}{l}\text { ethyl acetate } \\
\text { extract of bark }\end{array}$ & 0.64 & 0.73 & 0.69 & $15.61 \pm 5.48$ \\
\hline 2. & $\begin{array}{l}\text { methanol } \\
\text { extract of bark }\end{array}$ & 0.63 & 0.56 & 0.54 & $28.94 \pm 5.73$ \\
\hline 3. & $\begin{array}{c}\text { n-hexane } \\
\text { extract of fruit }\end{array}$ & 0.62 & 0.52 & 0.68 & $25.16 \pm 10.22$ \\
\hline 4. & $\begin{array}{l}\text { methanol } \\
\text { extract of fruit }\end{array}$ & 0.64 & 0.69 & 0.54 & $23.26 \pm 9.10$ \\
\hline 5. & $\begin{array}{c}\text { methanol } \\
\text { extract of leaf }\end{array}$ & 0.56 & 0.57 & 0.56 & $30.59 \pm 0.63$ \\
\hline 6. & Kojic acid & 0.29 & 0.28 & 0.28 & $65.07 \pm 0.86$ \\
\hline
\end{tabular}

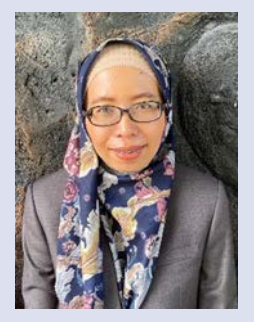

Dr. Neneng Siti Silfi Ambarwati, a Lecturer at the Cosmetology Department, Faculty of Engineering, Universitas Negeri Jakarta, East Jakarta, Indonesia. The research focused on natural products for drug and cosmetic discovery and development, extraction technology, and cosmetic ingredients (cosmeceuticals).

Prof. Dr. Berna Elya is a Professor and Lecturer at the Department of PharmacognosyPhytochemistry, Faculty of Pharmacy, University of Indonesia. She develops works in the field of pharmacognosy, phytochemistry, and natural material chemistry.

Dr. Yesi Desmiaty, A lecturer and researcher at Faculty of of Pharmacy, University of Pancasila, Jakarta, Indonesia. Her research focused on natural products, pharmacognosy, Indonesian herbal plants, and anti skin aging. 


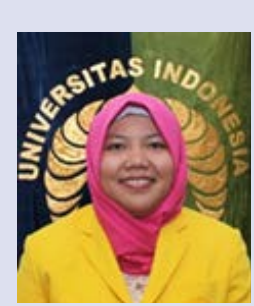

Ayun Erwina Arifianti is a master graduate and currently working as an academic staff in the Universitas Indonesia. She finished her bachelor's and profession's degree in the Faculty of Pharmacy, Universitas Indonesia and continued her master's degree also in the Faculty of Pharmacy, Universitas Indonesia majoring Pharmaceutical Technology. Despite her background in pharmaceutical sciences, Ayun has a big interest in various fields such as Herbal Medicines, Cosmetics, Microbiology, and Molecular Biology. She has published several papers in the pharmaceutical research and teaching courses both in pharmaceutical and health science.

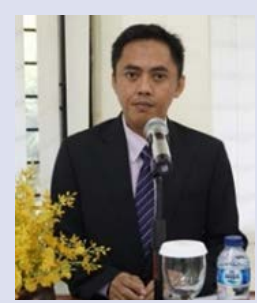

Dr. Islamudin Ahmad, Associate Professor at Department of Pharmaceutical Sciences, Faculty of Pharmacy, Universitas Mulawarman, East Kalimantan, Indonesia. He has experience in Pharmacognosy and Natural Product Chemistry, working in drug discovery of natural products, green extraction engineering, isolation and identification of active compounds, screening activity, and mainly degenerative diseases.

Cite this article: Ambarwati NSS, Elya B, Desmiaty Y, Arifianti AE, Ahmad I. Tyrosinase Inhibitory Activity of Garcinia latissima Miq. Extracts. Pharmacogn J. 2021;13(6)Suppl: 1673-1677. 